\title{
会合溶液論による気液平 衡
}

\section{はじめに}

気液平衡関係を定量的に把握するためには気相の非理 想性, 液相の非理想性を知らねばならない。しかし, 一 般に低圧では，特別の場合を除けば平衡関係全体として の非理想性のほとんどは，液相のそれに起因すると考え てよい。

混合液の非理想性を van Laar 式あるいは Hildebrand -Scatchard 式のように, 分子間力（分子間の物理的相互 作用）の違いに基つくくとする考えがあるが，これに対し て，ここにとりあげる会合溶液論は，溶液の非理想性を その名の示すように, 溶液中での分子間会合に起因する とするものである。

会合溶没㻆の源は古く, 1908 年の Dolezalek の報文 ${ }^{5)}$ にまでさかのぼることがでさる。この化学論的に溶液の 性質を説明しょうという解析法によると, 溶夜の正の非 理想性も, 負の非理想性も簡単に説明できるという長所 があるが, 一方, 会合性を全く考えることができないよ らな分子よりなる系についてる，液中での会合を考えな くてはならないという不合理を生じた。Dolezalek と同 じ時代に活躍した van Laar は溶液の非理想性を物理的 な分子間力の连いで説明する立場をとったため，この両 研究者の間でかなりの論争が行なわれたようである。

一般浽理想性の非常に大きな溶液に対し, その非理 想性の原因を物理的分子間力の違いのみで説明すること は困難で,たとえ何らかの式で表えしえたとしても, 式中 の定数は物理的意味の乏しい経験定数として报わざるを えなくなる。これに対し会合溶液論によると，このよう な大きな非理想性，あるいは基常な非理想性（たとえば 活量係数の濃度依存性が大きく非対称であったり, 極值 を持っているなど）を分子間会合によって適切に説明で きることが多い。また表現式中の定数にも物理化学的に はっきりとした意味を持たせることもでき，時には分光 学的手法によって溶液中での会合の様子を調べたり, そ

* 昭和 48 年 8 月 6 日受理

** Takashi Katayama (正会員) 大阪大学基硔工学部 化学工学科
の会合平衡定数を計算することも不可能ではない。

以上は主として会合溶液論の長所を述べたが，この理 論も種々の短所を持っている。まず第一にあげられるの がその系に適した会合様式を的確に選定することであ る。分子の会合も化学反応の一種と考えられるから，反 応の型式は多岐にわたり，一つの反応式に対して一つの 表現式を組み立てねばならない。第二に考えられるのが 連鎖反応も含めて種々の会合反応の共存である。一つの 会合反応に対して一つの表現式および反応平衡定数を考 えるならば, 共存する反応の数に比例して必要とする関 俰式および平衡定数は増大し，何らかの大胆な仮定を用 いない限り基本式が複雑になってしまう。最近の分光学 の進歩によって，溶液中の会合分子の存在認定がしたい に可能になってきたことが, 1950 年ごろから会合溶液論 が再諗識されてきた原因の一つと考えられる。また，最 近の電子計算機の発達によって計算基礎式の複雑さがあ る程度許されるようになってきたことも，この理論の再 認識に一役かっているといえるであろう。

会合溶液理論を取り扱っている成書としてはPrigogine-Defay ${ }^{19)}$; 藤代-黒岩 ${ }^{7)}$, Hildebrand-Scott ${ }^{9)}$, Prausnitz $^{18)}$ らのものがあげられる。ここではこれらの成書お よび学会誌の中から,この理論を理解する上で最も基礎 的な考え方を述べたのち，代表的な文献ならびに最近の 報告の一部について簡単に紹介する。昨年, 筆者 ${ }^{10)}$ は会 合溶液論による気液平衡についてここに述べると類似の 解説を行なったことがあるので参照されたい。なお， Barker $ら^{2,3)}$ の準結晶格子模型による取り扱い（分子の 表面をさらに接触面の集りと考兄, 各接触面が互いに異 なる相互作用力を持つものとして, 各接触面対エネルギ 一の総和として系全体のエネルギーを考劣る）はこれか ら述べる会合理論とは異質なので, ここではとりあげて いない。

\section{1. 会合モデル}

会合溶液理論を用いる場合，最も重要な点はその溶液 
鎖状会合<smiles>[R]ONC(C)(C)N[Z]([R])(C)OP</smiles>

瑾状会合

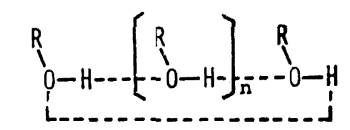

二次元会合

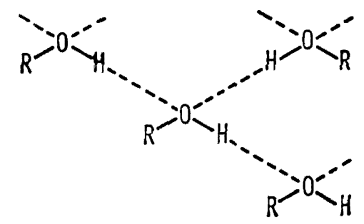

图 1 アルコール類の会合モデル

に適した会合モデルの選定であり、この選定を誤れば有 用な結果はえられない。会合様式は溶液中の成分分子の 化学構造より不完全ながら推定が可能であり，また時に は分光学的手法によって認知することも可能である。会 合の型式には大別して同種分子間会合 (Association) と 異種分子間会合（やはり Association という語が使われ るが, Complex formationあるいは Solvation とも呼ば れる) がある。

A 分子の同種分子間会合 (自己会合ともいう) を式で 示せば

$$
n \mathrm{~A}_{1} \rightleftarrows \mathrm{A}_{n}
$$

となり， $n$ としては 2 以上のいずれの整数も考光られ る。アルコール類 $(\mathrm{R}-\mathrm{OH})$ の自己会合について考えて みると, 一 $\mathrm{OH}$ 基に含まれる $\mathrm{H}$ が他の分子の $\mathrm{O}$ との間 に水素結合をする図1のようなモデルが考えられるが， どの種のものが実在するか，また会合分子数 $n$ はいくら か, については論議の多いところである。

異種分子間会合に対して，一般式は

$$
n \mathrm{~A}_{1}+m \mathrm{~B}_{1} \rightleftharpoons \mathrm{A}_{n} \mathrm{~B}_{m}
$$

で与えられる。古くよりよく知られている例としてはア セトンークロロフォルム，クロロフォルムーエチルエーテ ルのように式 (2) に拈いて $n=m=1$ とした会合（最近 は異論もある）がある。

いま，溶液中に単分子として存在するとしたときのA 分子, $\mathrm{B}$ 分子のそれぞれの全モル数を $n_{A}, n_{B}$ とし，こ の 2 成分系溶液が式 (1), 式（2）で示されるような会合 をしているときを考えると，収支の考えより

$$
\begin{aligned}
& n_{A}=\sum_{i} i n_{A_{i}}+\sum_{k} \sum_{l} k n_{A_{k} B_{l}} \\
& n_{B}=\sum_{j} j n_{B_{j}}+\sum_{l} \sum_{k} l n_{A_{k} B_{l}}
\end{aligned}
$$

となり。この両式と後に定義する会合定数によって，溶 液中の分子種分布加定まる。

\section{2. 会合溶液理論}

\section{2 -1 熱力学的基本関係 ${ }^{19)}$}

A，B 2 成分系 (以下すへて 2 成分系に限る) が溶液 中で自己会合 $\mathrm{A}_{i}, \mathrm{~B}_{\boldsymbol{j}}$ 扎よび異種分子間会合 $\mathrm{A}_{k} \mathrm{~B}_{l}$ を形 成している一般的な場合を考えてみると，会合分子と単 分子は化学平衡の状態にあることから

$$
\left.\begin{array}{rl}
\mu_{A_{i}} & =i \mu_{A_{1}} \\
\mu_{B_{j}} & =j \mu_{B_{1}} \\
\mu_{A_{k} B_{l}} & =k \mu_{A_{1}}+l \mu_{B_{1}}
\end{array}\right\}
$$

が得られる。溶液全体の自由エネルギーGは各分子種に 着目して表わせば

$$
G=\sum_{j} n_{A_{i}} \mu_{A_{i}}+\sum_{j} n_{B_{j}} \mu_{B_{j}}+\sum_{k} \sum_{l} n_{A_{k} B_{l}} \mu_{A_{k} B_{t}}
$$

となりまた巨視的に考えた A 分子， B 分子の化学ボ テンシャル $\mu_{A}, \mu_{B}$ を用いて書き表わすと

$$
G=n_{A} \mu_{A}+n_{B} \mu_{B}
$$

となる。式（2）（7）を組合せてみれば

$$
\left.\begin{array}{l}
\mu_{A}=\mu_{A_{1}} \\
\mu_{B}=\mu_{B_{1}}
\end{array}\right\}
$$

となる。すなわち，巨視的に考えた各成分の化学ポテン シャルは溶液中におけるその成分の単分子の化学ポテン シャルに等しいといら重要な関係が得られる。そして, この関係は会合の様式やその複雑さには関係なく，熱力 学的な平衡にさえあれば成立する。

\section{$2 \cdot 2$ 理想会合溶液 7,19 )}

会合分子を新しい分子種とみなすとして，単体む含め た各分子種がどのような状態で溶液を形成していると考 えるかで，異なった会合溶液理論が導かれる。各分子種 の大きさの違いなどを一切無視して，各分子種は理想溶 夜を形成するとみなす最も簡単な取り扱いが，ここで述 ベる理想会合㾂液である。

いま溶液中の $\mathrm{A}_{i}$ 分子種について化学ポテンシャル $\boldsymbol{\mu}_{\boldsymbol{\Delta}_{i}}$ を考えてみると，理想溶液に対する一般の熱力学的 関係より

$$
\mu_{\Delta_{i}}=\mu_{\Delta_{i}}{ }^{*}+R T \ln x_{\Delta_{i}}
$$

が成立する ( $R$ は気体定数, $T$ は絶対温度)。ここで $\mu_{\boldsymbol{A}_{i}}{ }^{*}$ は $\mathrm{A}_{1}$ 分子種が純粋状態（仮想状態になる）で存在した ときの化学ポテンシャルであり，また， $x_{A_{i}}$ は溶液にお ける $\mathrm{A}_{\mathbf{l}}$ 分子種の実効モル分率で，次式で示される值で ある。

$$
x_{A_{i}}=\frac{n_{\Delta_{i}}}{\sum_{i} n_{\Delta_{i}}+\sum_{j} n_{B_{j}}+\sum_{k} \sum_{!} n_{\Delta_{k} B_{i}}}
$$

溶液中での巨視的にみたA成分の対称基準方式による 活量係数を $\gamma_{\Delta}$ で表わせば， $\mu_{\Delta}$ は純粋 A 成分の化学ポ テンシャル $\mu_{\Delta}^{0}$ を用いて 


$$
\mu_{\Delta}=\mu_{A}{ }^{0}+R T \ln \gamma_{\Delta} x_{A}
$$

で示される。ここで $x_{A}$ は普通に用いられている巨視的 にみた場合の溶液中におけるA成分のモル分率である。 式（9）を $i=1$ としてAの単分子種 $A_{1}$ に対する式と し，式 (8)，(11）の関係を用いれば

$$
\ln \gamma_{\Delta}=\ln \frac{x_{\Delta_{1}}}{x_{A}}+\frac{\left(\mu_{A_{1}}{ }^{*}-\mu_{A}{ }^{0}\right)}{R T}
$$

がえられる。 $x_{\boldsymbol{A}} \rightarrow 1$ のとき，すなわち $\mathrm{A}$ 成分が純粋な ときに，単分子として存在している実効モル分率 $x_{A_{1}}{ }^{0}$ は ある值 $\left(x_{A_{1}}{ }^{0} \leqq 1\right)$ をとり，定義よりこのとき $\gamma_{A} \rightarrow 1$ と なるので，この関係を式 (12) に代入すれば

$$
\ln x_{A_{1}}{ }^{0}=-\frac{\left(\mu_{A_{1}}{ }^{*}-\mu_{A}{ }^{0}\right)}{R T}
$$

が得られる。そして式 (12)，（13）より

$$
\gamma_{A}=\frac{1}{x_{A_{1}}{ }^{0}} \cdot \frac{x_{A_{1}}}{x_{A}}
$$

の関係が導かれる。

今まではA成分について述へててきたが，全く同様にし $\tau, B$ 成分について子

$$
r_{B}=\frac{1}{x_{B_{1}}{ }^{0}} \cdot \frac{x_{B_{1}}}{x_{B}}
$$

の関係が導かれる。式 (14)，(15）より判るように $\gamma_{\Delta}$, $\gamma_{B}$ の值は $x_{A_{1}{ }^{0}}, x_{A_{1}} / x_{A} お$ よび $x_{B_{1}}{ }^{0}, x_{B_{1}} / x_{B}$ の值が判 れば求まるが，実際に計算するためには会合の様式と会 合の強さを知る必要がある。

放モデル 1. A成分の自己会合のみある場合（会合様 式不明, 理想会合)

いまA成分のみに自己会合がある系（たとえぱフルコ 一ル(A)一パラフィン系炭化水素 (B) のような系), すなわち，溶液中には $\mathrm{A}_{1}, \mathrm{~A}_{2}, \cdots \cdots, \mathrm{A}_{i}, \cdots \cdots, \mathrm{B}_{1}$ が存在 する場合には $x_{\boldsymbol{A}_{1}{ }^{0}}{ }^{2}$ は， $x_{\boldsymbol{A}_{1}}{ }^{0}<1$ のある値を持ち，また $x_{\Delta_{1}}{ }^{0} \leqq x_{A_{1}} / x_{A} \leqq 1$ の関係にあることから, 全濃度範囲に おいて $\gamma_{\Delta} \geqq 1$ の関係が成立する。そして $x_{A} \rightarrow 0$ では A 分子は単分子としてのみ存在することから, $x_{A_{1}} / x_{A} \rightarrow 1$ となり， $\left(\gamma_{A}\right)_{x_{A} \rightarrow 0} \rightarrow 1 / x_{A_{1}}{ }^{0}$ となる。B 成分について子類 似の考察ができ，全濃度範囲において $\gamma_{B} \geqq 1$ の関俰が成 立することがわかる。すなわち，このモデルの溶液では 常に Raoult 則より正の偏倚を示すことが定性的に求め られる。しかしながら，ケ。の值を定量的に求めるために は，会合の様式とその強さをはっきり知らねばならな W。

々モデル2. A 成分の自己会合のみある場合 (平衡定 数一定の連続会合様式，理想溶液 $)^{18)}$

A分子はつぎつぎと限りなく鎖状に会合していけるも の(すなわち，溶液中には $\mathrm{A}_{1}, \mathrm{~A}_{2}, \cdots \cdots, \mathrm{A}_{1}, \cdots \cdots, \mathrm{B}_{1}$ か 存在する）とし, $i-1$ 量体と $i$ 量体との平衡定数を

$$
K_{\Delta_{i}}{ }^{(x)} \equiv \frac{x_{\Delta_{i}}}{x_{\Delta_{i-1}} x_{A_{i}}}
$$

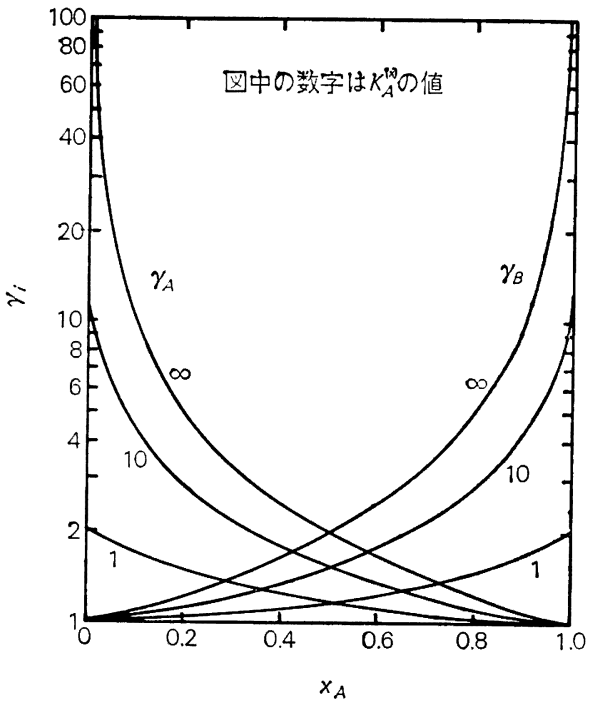

图 $2 \quad \mathbf{A}_{1}+\mathbf{A}_{2}+\cdots \cdots+\mathbf{A}_{\imath}+\cdots \cdots+\mathbf{B}_{1}$ モデルの $\gamma_{i}$ 対 $x_{A}$ (理想会合溶液) ${ }^{18)}$

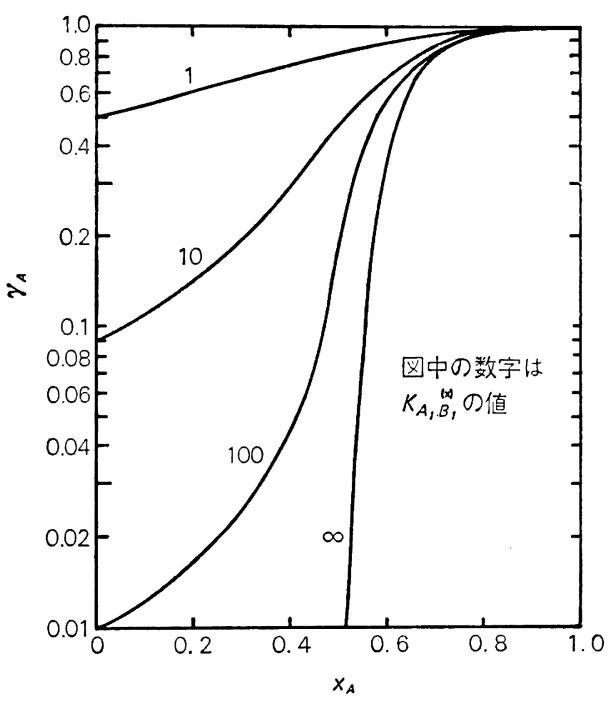

图 $3 \quad A_{1}+B_{1}+A_{1} B_{1}$ モデルの $\gamma_{A}$ 対 $x_{A}$ (理想会合溶液 ${ }^{18)}$

で定義し、また各平衡定数は

$$
K_{A_{2}}{ }^{(x)}=K_{A_{a}}{ }^{(x)}=\cdots \cdots=K_{A_{i}}{ }^{(x)}=\cdots \cdots=K_{A}{ }^{(x)}
$$

で示されるように皆同じ值であると仮定できると， $\gamma_{A}$ は

$$
\gamma_{A}=\frac{2\left(K_{A}^{(x)}+1\right)}{1+2 K_{A}^{(x)} x_{A}+\left(1+4 K_{A}^{(x)} x_{A} x_{B}\right)^{1 / 2}}
$$

となる。式（18）を $x_{\Delta} \rightarrow 0$ において適用すると

$$
\lim _{x_{A} \rightarrow 0} \gamma_{A}=1+K_{A}{ }^{(x)}
$$

の簡単な関係が得られる。一方 $\gamma_{B}$ の值は

$$
\gamma_{B}=\frac{2\left(K_{A}^{(x)}+1\right)}{1+2 K_{A}^{(x)} x_{B}+\left(1+4 K_{A}^{(x)} x_{A} x_{B}\right)^{1 / 2}}
$$




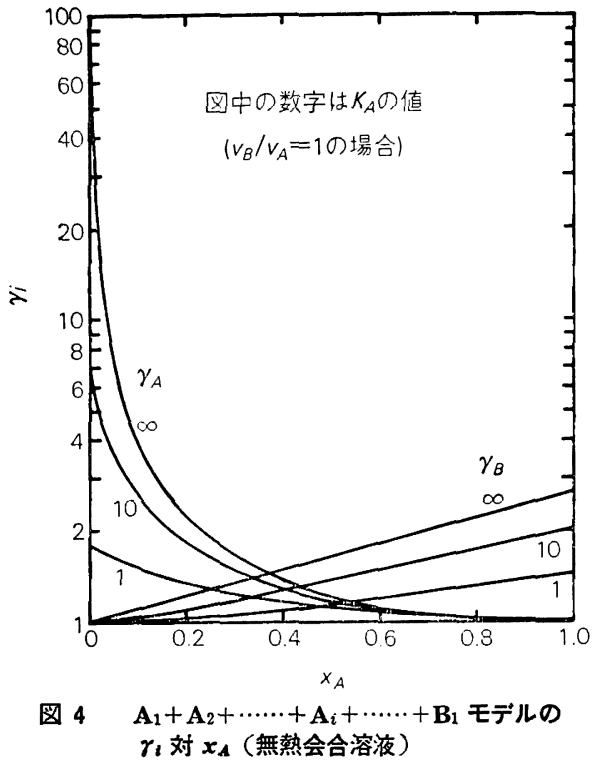

となる。図2 $2 K_{A}^{(x)}$ の值を变化させて計算した $\gamma_{A}, \gamma_{B}$ の値を示したもので，図からも，また式 (18)，（20）か らも判るように, この場合 $\gamma_{A}$ と $\gamma_{B}$ は $x_{A}=0.5$ の㖕に 対して対称的な值を与える。

々モデル 3. 異種分子間のみに 1 対 1 の会合がある場 合 (理想溶液) ${ }^{18)}$

溶液中に $\mathrm{A}_{1}, \mathrm{~B}_{1}, \mathrm{~A}_{1} \mathrm{~B}_{1}$ のみが存在するときで,この場 合異種分子間会合定数 $K_{A_{1} B_{1}}{ }^{(x)}$ を

$$
K_{A_{1} B_{1}}{ }^{(x)} \equiv \frac{x_{A_{1} B_{1}}}{x_{A_{1}} x_{B_{1}}}
$$

と定義して計算を行なえば

$$
\begin{aligned}
& \gamma_{A}=\frac{4-k^{\prime}}{2-k^{\prime} x_{A}+2\left(1-k^{\prime} x_{A} x_{B}\right)^{1 / 2}} \\
& \gamma_{B}=\frac{4-k^{\prime}}{2-k^{\prime} x_{B}+2\left(1-k^{\prime} x_{A} x_{B}\right)^{1 / 2}}
\end{aligned}
$$

ここで

$$
k^{\prime} \equiv \frac{4 K_{A_{1} B_{1}}{ }^{(x)}}{K_{A_{1} B_{1}}{ }^{(x)}+1}
$$

となる。式（22）と式（23）の比較から判るように, こ のモデルでも $\gamma_{A}, \gamma_{B}$ の值は $x_{A}=0.5$ に対して対称であ る。 $K_{A_{1} B_{1}}{ }^{(x)}$ を変化させて計算した $\gamma_{\Delta}$ 対 $x_{A}$ の関係を

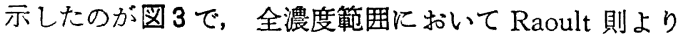
負の㣂倚を与える。この種の会合を示すものとしてはア セトンークロロフォルム系(最近は異論もある)があり, Hildebran」 $ら^{9)}$ の著書には計算値と実測値との比較が 示されている。

* 無䓡会合溶液 (Athermal associated mixture) は無熟溶液諭の考 えを会合溶液に適用したことから出てきた用語で，Kehiaian らの報

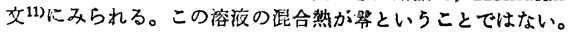

\section{$2 \cdot 3$ 無熱会合溶液 ${ }^{13,21,12,18)}$}

前述の理想会合溶液の取り扱いでは分子の大きさの差 異を無視してきた。しかし，特に会合分子が存在する場合 には分子の大きさの差異を考兄ないわけにはいかない。 そこで高分子溶夜のように，大きさの異なる分子を含む 系に特に有用な Flory-Huggins によって導かれた無熱 溶液理諭 ${ }^{18)}$ の適用が考えられる。この考劣に従って, 溶 液中にはいろいろの会合分子種の存在をみとめ,この新 しい会合分子種も含めて，各分子は無熱容液を形成する と仮定したのが，ここでいら無熱会合溶液*である。こ の仮定に従って式を展開していくと式（14），(15）に対 応する関係式として

$$
\begin{gathered}
\gamma_{A}=\frac{\phi_{A_{1}}}{\phi_{A_{1}}{ }^{0} x_{A}} \exp \left(\frac{\phi_{A_{1}}{ }^{0}}{x_{A_{1}}{ }^{0}}-\frac{\phi_{A_{1}}}{x_{A_{1}}}\right) \\
\gamma_{B}=\frac{\dot{\phi}_{B_{1}}}{\phi_{B_{1}}{ }^{0} x_{B}} \exp \left(\frac{\phi_{B_{1}}{ }^{0}}{x_{B_{1}}{ }^{0}}-\frac{\phi_{B_{1}}}{x_{B_{1}}}\right)
\end{gathered}
$$

が得られる ${ }^{122} 。 こ こ に \phi_{A_{1}}$ は溶液中におけるA 分子の 単量体の容積分率を表わし， $\phi_{A_{1}}{ }^{0}$ は $\mathrm{A}$ 分子が純粋な場 合の $\phi_{A_{1}}$ の値である。理想会合溶液理論の場合と同様, 会合様式と会合強さより単量体分率が求まれば式(25), （26）より $\gamma_{A}, \gamma_{B}$ の値を知ることができる。 约モデル 4. A分子の自己会合のみある場合（平衡定 数一定の連続会合様式, 無熱溶液 $)^{182}$

会合様式はモデル2.の場合と同じく A成分のみが無限 に鎖状会合しらると仮定する。無熱会合溶液理論を用い る場合に適切と思われる平衡定数としてつぎのようなる のが考えられる。

$$
K_{A_{i}}{ }^{(c)} \equiv \frac{C_{A_{i}}}{C_{A_{i-1}} C_{A_{i}}}
$$

ここで $C_{A_{i}}$ は $\mathrm{A}_{i}$ 分子種のモル濃度 $[\mathrm{mol} / \mathrm{m} l]$ である。 いまvをモル容積 $[\mathrm{m} l / \mathrm{mol}]$ とし

$$
v_{A_{i}}=i v_{A_{1}}=i v_{A}
$$

が成り立つとする。そして無次元の平衡定数 $K_{A_{i}}$ を

$$
K_{A_{t}} \equiv \frac{K_{A_{t}}(c)}{v_{A}}
$$

とすれば

$$
K_{A_{i}}=\frac{\phi_{A_{i}}}{\phi_{A_{i-}} \phi_{A_{1}}} \cdot \frac{i-1}{i}
$$

の関保がある。いま

$$
K_{A_{2}}=K_{A_{2}}=\cdots \cdots=K_{A_{1}}=\cdots \cdots=K_{A}=K_{A}^{(c)} / v_{A}
$$

すなわち，式 (29)，(27）で定義された $K_{A_{i}}, K_{A_{i}}{ }^{\left({ }^{(0)}\right.}$ が $i$ によらず一定で，それぞれ $K_{A}, K_{A}{ }^{(c)}$ で与克られると すると、このモデルを用いた場合の溶液中の分子種分布 を計算することができ ${ }^{10)}$ ，式 (25)，(26）の基礎式を用 いて $\gamma_{A}, \gamma_{B}$ の值を知ることができる。その計算結果の み示せば, 


$$
\begin{aligned}
\ln \gamma_{A}= & \ln \left(\phi_{A}+\frac{v_{A}}{v_{B}} \phi_{B}\right) \\
& +\ln \frac{1+2 K_{A}+\left(1+4 K_{A}\right)^{1 / 2}}{1+2 K_{A} \phi_{A}+\left(1+4 K_{A} \phi_{A}\right)^{1 / 2}} \\
& +\frac{2}{1+\left(1+4 K_{A}\right)^{1 / 2}}-\frac{2 \phi_{A}}{1+\left(1+4 K_{A} \phi_{A}\right)^{1 / 2}} \\
& -\frac{v_{A}}{v_{B}} \phi_{B} \\
\ln \gamma_{B}= & \ln \left(\phi_{B}+\frac{v_{B}}{v_{A}} \phi_{A}\right)+\phi_{A} \\
& -\frac{v_{B}}{v_{A}} \cdot \frac{2 \phi_{A}}{1+\left(1+4 K_{A} \phi_{A}\right)^{1 / 2}}
\end{aligned}
$$

である。 $v_{B} / v_{A}=1$ の場合について, $\gamma_{A}, \gamma_{B}$ の值と $x_{A}$ 之 の関係をプロットしたのが図 4 で,これと図 2 を比較す れば归熱会合溶液と理想会合溶液との差翼がよくわか る。

\section{3. 会合溶液理論を用いた気液平衡の研究}

今までは会合性溶液に対する基礎的熱力学関係式と, 会合モデルおよび会合平衡定数を定めた場合，会合性 に起因する溶液の非理想任はいかに表わされるかを示し た。しかし，宇際の系に適用した最近の研究にはこのは かに物理的相互作用項をむ加味して溶夜の非理想性を表 わすことが多く，また，会合性についても同種分子間之 異種分子間会合が共存した系を扱ったものもみられる。 これらの㣫々の違いの組合せを考えても判るよらに, 会 合溶液理論を用いた研究の種類は実に複雑多岐である。 ここでは基礎的な注目されるべきと思われる報告につい てのみ簡単な紹介を行なら。

\section{¿́solezalek ${ }^{5,6)}$}

会合溶液理論を用いて溶液の非理想性を示そらと試み た最初の研究である。アセトンークロロフォルムなどの 系について Raoult 則よりの負の偏倚勍明できた。し かし前にる述べたようにすべての非理想性を会合現象 のみで解決しようとしたため不合理を生じた。

\section{$\lesssim$ Redlich-Kister ${ }^{20)}$}

連続鎖状会合モデルをA成分に適用し，非会合のB成 分との溶液について，理想会合溶液理諭を用いた基本式 （物理的相互作用項も含む）を導き，アルコールー㘸化水 素系の気液平衡データとの比較を行なった。 iskretschmer-Wiebe ${ }^{13)}$

現在でも最もよく引用される文献で, 無熱会合溶液理 論を用いている。基本的には過剰自由エネルギー $g^{E}$ を 化学的な部分と物理的な部分からなるとした（Kretschmer らの文献ではこの分離は明確ではない)。

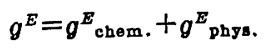

そして $g^{E}{ }_{\text {chem. }}$ に対しては無熱会合溶液理論を用い， $\mathrm{A}$
成分の自己会合のみを考え，平衡定数は式（30),（31） が成立する場合をとりあげた。すなわち $\gamma_{A}, \gamma_{B}$ の化学 的な部分は式 (32)，(33）で与えられる $\left(g^{E}\right.$ chem. はそれ らの ケ,の值より求められる)。

これに対し，物理的相互作用項 $g^{E}$ phys. には Hildebrand-Scatchard 式として知られている1パラメーター式

$$
g_{\text {phys. }}^{E}=b \phi_{A} \phi_{B}\left(x_{A} v_{A}+x_{B} v_{B}\right)
$$

を用いる。ここで $b$ はパラメーターである。式（35）よ り $\left(\gamma_{A}\right)_{\text {phys., }}\left(\gamma_{B}\right)_{\text {phys. }}$ は

$$
\begin{aligned}
& \ln \left(\gamma_{A}\right)_{\text {phys. }}=b v_{A} \phi_{B}{ }^{2} / R T \\
& \ln \left(\gamma_{B}\right)_{\text {phys. }}=b v_{B} \phi_{A}{ }^{2} / R T
\end{aligned}
$$

で与えられる。したがって

$$
\ln \gamma_{i}=\ln \left(\gamma_{i}\right)_{\text {chem. }}+\ln \left(\gamma_{i}\right)_{\text {phys. }}
$$

として表わされ，自己会合のある A 成分の活量係数 $\gamma_{A}$ は式（32）と式（36）の和として，また会合のないB成 分について, $\gamma_{B}$ は式 (33) と式 (37) の和として得ら れることになる。これらの関係式中でのパラメーターは $K_{\Delta}$ と $b$ であり, Kretschmer-Wiebe は 5 種類のアルュ ールー炭化水素系の気液平衡値に対して計算を行ない, これらのパラメーターの値を表示している。

¿̂Renon-Prausnitz ${ }^{21,18)}$

式（34）に従って基本式を組み立てており，会合モデ ル, 会合理諭, 物理的相互作用項 $b$ の導入など, Kretschmer-Wiebe ${ }^{13)}$ と全く同じである。対象としたのも同 じアルコールー炭化水素系溶液であるが, Renon らは解 析にあたって混合熱データもあわせて考えに入れ重視し た。混合熱に対する関係式は $g^{E}$ の基本式が与えられれ ば熱力学関係式によって求めることができる。

$K_{A}$ の温度変化は熱力学関係式によって水素結合エネ ルギー $\Delta h_{A}^{*}$ にむすびつけられる。

Renon らは $K_{A}, \Delta h_{A}{ }^{*}, b$ および $d b / d T$ の四つのパラ メーターを用いてデータの解析を試みている。最近, こ の Renon-Prausnitz に類似の手法を用いた報告が長田 $5^{15)}$, 新田ら ${ }^{17)}$ によって提出されている。

cotwiehe $5^{22,23)}$

Wiehe-Bagley $^{22)}$ は同じくアルコール-炭化水素系を 対象として無熱会合溶液理論を用いて解析を行なってい る。たたし物理的相互作用項は用いていない $\left(\ln \left(\gamma_{i}\right)_{\mathrm{phys} .}\right.$ =0)。また会合平衡定数としては

$$
K_{\Delta}^{(\phi)} \equiv \frac{\phi_{A_{i}}}{\phi_{A_{t-1}} \phi_{A_{i}}}
$$

で与えられる $K_{A}{ }^{(\phi)}$ を定義し， $K_{A}{ }^{(\phi)}$ を $i$ 無関係に一 定とした。式（39）の関係を用いて式（25），(26）を変 形すれば

$$
\begin{aligned}
\ln \gamma_{A}= & -\left(1+\frac{1}{K_{A}{ }^{(\phi)}}\right) \ln \left(x_{A}+\frac{\rho}{1+K_{A}^{(\phi)}} x_{B}\right) \\
& -\frac{x_{B}}{\rho x_{B}+x_{A}}+\frac{1}{K_{A}^{(\phi)}} \ln \left(x_{A}+\rho x_{B}\right)
\end{aligned}
$$




$$
\begin{aligned}
\ln \gamma_{B}= & -\left(1-\frac{\rho}{K_{A}{ }^{(\phi)}}\right) \ln \left(x_{B}+\frac{1}{\rho} x_{A}\right)+\frac{x_{A}}{\rho x_{B}+x_{A}} \\
& -\frac{\rho}{K_{A}{ }^{(\phi)}} \ln \left(x_{B}+\frac{1+K_{A}^{(\phi)}}{\rho} x_{A}\right)
\end{aligned}
$$

が得られる。ここに $\rho=v_{B} / v_{A}$ である。しかし Wiehe ら は $\rho$ をモル容積の比としてではなく，その系に対するパ ラメーターとして取り扱い，各系に対して $K_{A}{ }^{(\phi)}, \rho$ の 值を求めた。

Wiehe-Dorai-Rader-Chandrasekhar ${ }^{23)}$ は後の報告に おいて前報 ${ }^{22)}$ の挔張を試みている。抬張された式は 2 ハ ラメーターの Flory-Huggins 式に同種分子および異種分 子間の会合性を組合せたもので, フルュールと二つの非 会合性溶媒よりなる 3 成分溶液に適用できる基礎式を出 している。そしてこの式を 2 成分系， 3 成分系気液平衡 の計算に用いているがその詳細は原報を参照されたい。

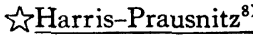

異種分子間会合があり, 溶液中に $\mathrm{A}_{1}, \mathrm{~B}_{1}, \mathrm{~A}_{1} \mathrm{~B}_{1}$ が存在 する場合について取り扱っている。ここでは平衡定数と して

$$
K_{A_{1} B_{1}}{ }^{(a)} \equiv \frac{a_{A_{1} B_{1}}}{a_{A_{1}} a_{B_{1}}}=\frac{\gamma_{A_{1} B_{1}} x_{A_{2} B_{1}}}{\gamma_{A_{1}} x_{A_{1}} \gamma_{B_{1}} x_{B_{1}}}
$$

で示されるような, 活量 $a$ の比として与えられる異種分 子間会合定数 $K_{A_{1} B_{1}}{ }^{(a)}$ を用いている。そして式 (42) の 右辺に示された活量係数に対しては van Laar 式に Flory-Huggins の混合エントロピー項を加えた関係が成立 するとした。Harris らはこれらの仮定にたってアセチレ ンの各種有機溶媒への溶解度を相閉し, 良好な結果を得 ている。

頼実ら ${ }^{24)}$ は Harris らの解析法を頼実らが実測した加 王下におけるェチレンの各種溶媒への溶解度に適用し， よい相関をえている。

\section{放 $\mathrm{A}_{i}, \mathrm{~B}_{1}, \mathrm{~A}_{k} \mathrm{~B}_{1}$ の共存モデル}

同種分子の連続会合と異種分子間会合が共存する場合 で，アルコールの自己会合とアルコールと溶媒分子との 会合が存在する系によく用いられるモデルである。この 場合同種分子間，異種分子間会合定数を必要とし，関係 式はかなり複雑になってくる。前述の Kretschmer らの 文献 ${ }^{13)}$ にはこのモデルによる簡単な考察がなされてお

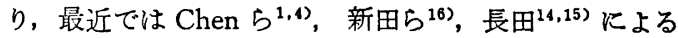
報告があり，前出の Wiehe $5^{23)}$ の文献中にも示されて いる。詳しくは原報を参照されたい。

店Kehiaian ${ }^{11)}$

Kehiaian とその協同研究者は, 1963 年以来 30 編にわ たる一連の会合溶液の熱力学に関する報文を発表してお。 り，会合モデル，溶液理論などの違いによる各種の計算 結果を与えている。しかしこれらは主として理論計算に のみ終始しており，実測值との比較はあまりみられない。

\section{おわりに}

Dolezalek によって先鞭をつけられた会合溶液理論に ついて, その最も基礎と思える理想会合溶液理論, 無熱 会合溶液理論を中心に, その理論的計算結果と応用を述 ベてきた。しかし，会合溶液理諭は実に複雑多岐にわた って展開されてきており，ここでは数多い報告の一部を 述へたたに過ぎない。また，ここでは気液平衡を中心に考 えたため，会合溶液の検討に重要な役割をはたす混合熱 の検討や, 液液平衡との関係, 並びに分光学的データと 熱力学的データとの比較などについては述べていない。

今まで会合溶液理論でとりあげられてきた物質として はアルコール類をはじめとした非水物質であり，代表的 会合性物質としてょく知られている水についての研究が みあたらないのは工学的立場からみて淋しく，今後の発 展を期待したい。

\section{引 用 文 献}

1) Bagley, E.B. and S.-A. Chen: J. Paint Technology, 41, 494 (1969)

2) Barker, J.A.: J. Chem. Phys., 20, 1526 (1952)

3) Barker, J.A. and F. Smith: ibid., 22, 375 (1954)

4) Chen, S.AA.: Sc.D. Dissertation, Washington Un.v., Saint Louis, Missouri (1969)

5) Dolezalek, F.: Z. physik. Chem., 64, 727 (1908)

6) Dolezalek, F. and A. Schulze: ibid., 83, 45 (1913)

7）落代充一，黒岩章晃：“溶液の性貿 I”, 東京化学同人, 東京(1966)

8) Harris, H.G. and J.M. Prausnitz: Ind. Eng. Chem., Fundamentals, 8, 180 (1969)

9) Hildebrand, J.H. and R. L. Scott: "The Solubility of Nonelectrolytes", 3 rd Ed., Dover Publications, Inc., New York (1964)

10）片山 湓：蒸留技術，2，No.3，6 (1972)

11) Kehiaian, H., et al.: The series paper "Thermodynamics of Chemically Reacting Mixtures", in Bull. Acad. Polon. Sci., Ser, sci. chim., I (1963)-XXX (1973)

12) Kehiaian, H. and A. Treszczanowicz: Bull. Acad. Polon. Sci, Ser. sci.chim., 14, 891 (1966)

13) Kretschmer, C. B. and R. Wiebe: J. Chem. Phys, 22, 1697. (1954)

14）長田 勇：Z. phys. Chem. (Leipzig)，252，305 (1973)

15）長田, 太田, 内山: J. Chem. Eng. Data, 18, 54 (1973)

16）新田, 片山: J.Chem. Eng. Japan, 6, 1 (1973)

17) 新田, 片山: ibid, 6, 224 (1973)

18) Prausnitz, J.M.: "Molecular Thermodynamics of FluidPhase Equilibria", Prentice-Hall, Inc, Englewood Cliffs, N. J. (1969)

19) Prigogine, I. and R. Defay: "Chemical Thermodynamics" Chapter 26, Longmans Green, London (1960) [姝尾学(敖) “化学熱力学”, 26 章, 久すず害房, 東京 (1966)]

20) Redlich, O. and A.T. Kister: J. Chem. Phys., 15, 849 (1947)

21) Renon, H. and J. M. Prausnitz: Chem. Eng. Sci., 22, 299: Errata, 1891 (1967)

22) Wiehe, I. A. and E. B. Bagley: Ind. Eng. Chem., Fundamentals, 6, 209 (1967)

23) Wiehe, I. A., et al.: Chem. Eng. Sci., 26, 901 (1971)

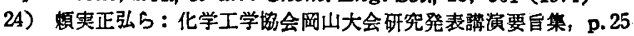
(1972) 